\title{
Struggling for Identification: Female Identity and Queer Representation in Li Yu's Films
}

\author{
Yinan Li \\ London School of Economics and Political Science, Gender Institute, London \\ Nico_LI_LI_Yinan@foxmail.com
}

\begin{abstract}
This article aims to provide a historical analysis of the cinematic representation of female identity and queer sexuality based on Li Yu films (Dam Street and Fish and Elephant) in comparison with Urban (Sixth) Generation film directors. This article provides a detailed clarification on the ambivalent national construction of female identity that took place during the urbanization after the1980s. The term Chinese term "women's cinema" has a close connection with social construction and political implication of female collective identities. Among the number of Chinese female directors, $\mathrm{Li} \mathrm{Yu}$ is the first one to make a Chinese lesbian film. Li adopts the tradition of urban Generation directors in her early works: using non-professional actors and shooting in the documentaries' style. Li focuses on the dilemmas of minor female figures in a chaotic era of urbanization in which Li expresses her own humanitarian concerns of pain and suffering through a pessimistic aesthetic sentiment.
\end{abstract}

Keywords: Chinese cinema, female identity, queer, nationalism, urbanization, Sixth Generation directors, female directors.

\section{Introduction}

Chinese women's cinema has been a unique term created in 1980s in reference to feminist filmmaking under contemporary socialist social-political context (Berry, 1988). Unlike western feminist filmmaking, the term women's cinema adopts the special political character of Chinese women's movement in the 1980s (Berry, 1988). The term women's cinema first appears during the early 1980s along with first and second Generations of Chinese female directors. In spite of women's cinema referring to all films made by Chinese female directors, it does not mean that women's cinema serves the same purpose as feminist cinema. Chinese women's cinema reveals contradiction and ambivalence within its character as a result of national ideological control, which continues calling for "stability and unity" after students' demonstration movement in1986-1987 (Berry, 1988).

This article intends to demonstrate the way nationalism controls the influences in the cinematic representation of queer and female identities, especially lesbian identities and how urbanization has rendered an opportunity for Urban Generation female directors to voice for marginalized female identities.

\section{Invisible Male: Repressed Female Identity Under Male Gaze}

The absence of male characters is a dominant feature of $\mathrm{Li} \mathrm{Yu}$ films. The absence of male characters indicates problematic and exaggerated female positions in such female films, rather than feminist position that denies male dominant existence. Even though male characters do not appear during the story lines, they appear and change the plot development outside of narrationss (Tian, 2014). In Dam Street, Li Yu conveys a strong desire for female to achieve self-salvation from their physical and psychological suffering. In a number of $\mathrm{Li} \mathrm{Yu}$ films, water adopts a metaphorical meaning of female body, as well as female biological power.

$\mathrm{Li} \mathrm{Yu}$ expresses the unattainable hope of making peace with male dominance through selftransitional salvation and the reconstruction of female body (Tian, 2014). The male character is invisible in Dam Street. In turn, the void left by these characters is filled with male gaze at an omnipotent position through the use of narration. The absence of male characters creates a sentiment of emptiness alongside the plot development. Xiao Yun's desire for Xiao Yong makes male gaze 
visible. At the same time, Xiao Yong expresses dominant Oedipal discourses that assert sexual fantasizing of male.

In Dam Street, females are deprived of their right to voice. They are objectified as sexual tools and being viewed under male gaze. The camera exerts masculine power in $\mathrm{Li} \mathrm{Yu}$ films which are used to unveil female suffering by placing dominance on female characters. The camera becomes the substitute of the invisible male character, yet the difference between the male character and the camera is that female completely loses their power when fighting against the male gaze (camera). As such, female identity is forced submit to male dominant discourses. Females are forced to be obedient to social ideology of womanhood.

Psychological repression dominates female psyche through hegemonic and systematic national moral construction of femininity. Constant moral construction, along with a reinforced traditional culture, mainly Confucianism cost Chinese female their confidence and self-recognition, their selfawareness ability and their chance to escape from the control of patriarchy.

\section{Queer Dilemma: Stereotypical Female Roles in National Discourses}

\subsection{Queer Identity: Substitution of Masculine Discourse}

The theoretical development of queer theory during the 1990s brought heated discussion within the Chinese society. After 2000, a group of queers publicly declared their sexuality and challenged national heteronormative discourse. Fish and Elephant displays culture and humanitarian sensation towards marginalized queer minority. The binary opposition of heterosexuality and homosexuality, which exists within dominant national discourses segregates social groups and forcibly promotes a consistency that adheres to the moral ideology.

$\mathrm{Li} \mathrm{Yu}$ displays an attitude of tolerance towards sexual identification: a compromise is made between queer identities (represented by the heroine Xiao Qun, who admits her sexual orientation at the beginning of film, which was criticized by her uncle as pathological problem, which is a metaphorically representation patriarchy dominance) and hegemonic national discourse (represented by Xiao Qun's mother who adheres to nationalism framework). Queer theory exceeds such binary discourses; Butler (2011) argues that gender and sexuality is not assigned with biological sex, on the contrary, sex, gender and sexuality are performed within what Foucault (2012) refers to as "regulative discourses". Queer cinema (in this article particularly refers to as lesbian films) is marginalized from mainstream cinema and is segregated under national censorship control (Zhou, 2013a).

\subsection{Stereotypical Female: Kinship and Multiple Female Roles}

National regulation of sexuality that is excerpted via the family unit defines social division of female labour. National regulations are organized through the kinship system, which consists of the principles that categorize individuals into different social groups and social roles. Family relations are not necessary represented through their blood lines; it can also be formed through kinship distance. Moral codes construct the ethical obligations bonds by means of kinship. This creates nationalist regulation on the moral beaviour of the individuals, such as the Confucian filial piety.

Nationalist control rationalizes queer representation through assertion of the body unity of the elements of the Ying/Yang (Wu, 2001). Nationalism regards the lesbian identity as deviant form of representations of masculinity through female body. Lesbian identity is achieved through the balance of Ying (the femininity component) and Yang (the masculine component). Hence, the body union of queer identities conforms to Ying/Yang theory of the balance of Ying and Yang. National discourse of Ying/Yang perspective serves another transitional dialogue for heterosexuality that regulates sexual identity through the masculine and feminine binary.

Female films center on ethical dilemmas that relate to different themes such as human relations, the fear and the anxiety of departing from the family. These dilemmas are more typical in female experiences because women face more obstacles when they are forming self-individuality than men do. Irigaray (2013) puts forwards the "female genealogy" that replaces male dominant position in the Oedipus triangle. Women dig deep inside their own psyche through the process of becoming the other; 
the mutual acceptance of mother and daughter complete women's self-recognition journey. (Niu, 2014).

The stereotypical social identification restraints female intent of self-recognition. Hegemonic moral code forbids the reconstruction of kinship relations. Even a self-aware lesbian such as Xiao Qun fails to escape from hegemonic heteronormative discourses. Confucianism as well as the Yin/ Yang perspective, theoretically regulates a form of self-recognition that conforms to the fulfillment of social expectations of gendered obligations. Queer identity then becomes ambivalent because it adopts a hybridity of national construction of queer awareness, and part of queer identities that does not fit into nationalism framework. Thus, the struggle of queer subjects faces some inner obstacles that overturns cultural dominate discourses that is based on the binary opposition.

\section{Conclusion}

Chinese female filmmaking centers on representations of female subjectivity in a cinematic approach of representing female living conditions.

Li Yu's film films document women's suffering under male dominance without showing a feminist political stance in cinematic representations. On the contrary, Li Yu's film uses a feminist perspective in narrations of rewritten narratives for dominant patriarchal culture. Li Yu creates female fantasies and desire for the opposite sex through the absence of male characters who hold dominant power in the overturn of female fate. Urban geography constitutes a site of loss and confusion in which female experience suffering and self-awareness. National construction of female and queer identity operates within the family unit through moral regulations of the stereotypical female social obligations.

Li Yu's films reveal twisted cinematic representations of female and queer identity in the contemporary Chinese women's cinema that adheres to male dominate discourses. Rather than transforming female character into objects under the male gaze, female characters in Li Yu films are obedient to hierarchical nationalistic discourses as subjects of the absent of the male characters.

\section{References}

[1]. Berry, C. (1988). China "New "Women's Cinema". Camera Obscura, 6(3 18), 8-19.

[2]. Butler, J. (2011). Gender trouble: Feminism and the subversion of identity. London: Routledge.

[3]. Dai, J. H. (1995). Invisible women: Contemporary Chinese cinema and women's film. positions, 3(1), 255-280.

[4]. Dai, J. (2007). On female dilemma in "Dam Street". Journal of Wenzhou University (Social Science Edition), 20 (3), 34-38.

[5]. Foucault, M. (2012). Discipline \& punish: The birth of the prison. Vintage.

[6]. Irigaray, L. (2013). Elemental passions. Routledge.

[7]. Tian, X. Q. (2014). The Devil in the Bottle: The Man Who Is Not Present - The Psychoanalysis of Li Yu 's Films. Contemporary Films, 5, 014.

[8]. Kristeva, J. (1977). About Chinese Women. Translated by Anita Barrows. London: Marion Boyars.

[9]. Niu, B. L. (2014). Master of thesis (Lanzhou University), Chinese female director since the 21st century.

[10]. Wu, X. M. (2001). National Characteristics of Modern Chinese Women's Liberation Thought. Guizhou Social Sciences, 2, 015. 
[11]. Zhou, C. H. (2013a). "Fish and Elephant": Observation of marginalized groups, subversion of male order. Film review, (2), 47-47. 